\title{
Analisis Modal Sosial untuk Kesejahteraan Masyarakat Lokal (Studi pada Wisata Petik Jeruk di Dusun Borogragal, Desa Donowarih, Kecamatan Karangploso, Kabupaten Malang)
}

\author{
Social Capital Analysis For Welfare Local Community \\ (Study on the Tours Pick Oranges in the Hamlet of Borogragal, Village \\ Donowarih, District Karangploso, Malang Regency)
}

\author{
Rini Puji Lestari, Sevi Nur Latifa Musyaffa', Zahria Latifatulhanim, \\ Prayogi Aprilianto, ${ }^{\bowtie}$ Aprili Kristiani Simbolon, Irfanuddin, dan Azis Arief Anggara
}

DOI:https://doi.org/10.32781/cakrawala.v12i1.266

\author{
Received : 27 Januari 2018 \\ Accepted : 9 Mei 2018 \\ Published : 21 Mei 2018
}

\begin{abstract}
Abstrak:
Penelitian ini dilatarbelakangi oleh pengembangan wisata petik jeruk di Desa Donowarih dimana wisata petik jeruk tersebut dapat mendukung peningkatan kesejahteraan di masyarakat Desa Donowarih. Penelitian ini menggunakan jenis penelitian deskriptid dengan pendekatan kualitatif yang bertujuan untuk menganalisis modal sosial masyarakat Desa Donowarih untuk mendukung kesejahteraan masyarakat. Metode analisis yang digunakan dalam penelitian ini menggunakan metode analisis John Cresswel. Analisis didsarkan pada tiga dimensi modal sosial antara lain Jaringan (Network), Kepercayaan (Trust), Norma (Norms). Hasil dari penelitian menyatakan bahwa berdsarkan dimensi jaringan, Desa Donowarih sudah memiliki potensi jaringan dengan dinas-dinas terkait walaupun belum optimal. Jaringan yang dimiliki Desa Donowarih dengan desa-desa lain dan jaringan yang ada di masyarakat dapat diandalkan dalam pengembangan wisata petik jeruk. Berdasarkan dimensi kepercayaan, masyarakat dan pemerintah desa percaya bahwa wisata petik jeruk dapat meningkatkan kesejahteraan masyarakat. Namun, peneliti belum mendapatkan data yang cukup tentang kepercayaan antar elemen masyarkat dalam mengembangkan wisata petik jeruk Desa Donowarih. Sedangkan dari dimensi Norma, belum ada norma-norma formal yang mengatur tentang interaksi masyarakat dalam mengembangkan wisata petik jeruk. Namun, terdapat norma yang tentang sewa lahan oleh petani jeruk yang berpotensi untuk meningkatkan partisipasi masyarakat dalam pengembangan wisata petikjeruk Desa Donowarih.
\end{abstract}

Kata kunci: Modal Sosial, Kesejahteraan Masyarakat, Wisata Petik Jeruk.

\begin{abstract}
:
This research is motivated by the development of citrus citrus tourism in Donowarih Village where the citrus quotes can support the improvement of welfare in Donowarih Village community. This research uses descriptive research type with qualitative approach which aims to analyze social capital of Donowarih Village community to support community welfare. The method of analysis used in this study using John Cresswel analysis method. The analysis is based on three dimensions of social capital such as Network (Network), Trust (Trust), Norm (Norms). The result of the research states that based on the network dimension, Donowarih Village already has network potential with related offices although not yet optimal. The network owned by Donowarih Village with other villages and community networks is reliable in the development of citrus tour. Based on the belief dimension, the community and the village government officials believe that the citrus picking trip can improve the welfare of the community. However, researchers have not received enough data about the confidence among the elements of society in developing the tour of the citrus village of Donowarih. While from the dimensions of Norm, there are no formal norms that regulate the interaction of the community in developing the tour of citrus citrus. However, there is a norm about the lease ofland by citrus growers that have the potential to increase community participation in the development of citrus tourism of Donowarih Village.
\end{abstract}

Keywords: Social Capital, Community Welfare, Citrus Charity Tour.

How to Cite:

Rini Puji Lestari, Sevi Nur Latifa Musyaffa', Zahria Latifatulhanim, Prayogi Aprilianto, Aprili Kristiani Simbolon, Irfanuddin, dan Azis Arief Anggara (2018). Analisis Modal Sosial Untuk Kesejahteraan Masyarakat Lokal (Studi Pada Wisata Petik Jeruk di Dusun Borogragal, Desa Donowarih, Kecamatan Karangploso, Kabupaten Malang). Cakrawala, 12(1), 85-96

\footnotetext{
* Corresponding Author:

Nama : Aprili Kristiani Simbolon

Email : aprili.simbolon@yahoo.co.id

Contact
}

두 2018 Badan Penelitian dan Pengembangan Provinsi Jawa Timur p-ISSN 1978-0354 | e-ISSN 2622-013X 


\section{Pendahuluan}

Otonomi daerah lebih menitikberatkan aspirasi dan kondisi daerah, oleh sebab itu otonomi mencakup empat aktivitas. Pertama, membentuk perundangan sendiri (zelf wet' geving). Kedua, melaksanakan sediri (zelf uit'voering). Ketiga, melakukan peradilan sendiri (zelf recht'spraak). Keempat, melakukan tugas kepolisian sendiri (zelf poli'e). Makna otonomi daerah adalah: pertama, hak mengurus rumah tangganya sendiri; kedua, dalam kebebasan menjalankan hak mengurus dan mengatur rumah tangga sendiri tersebut, daerah dak dapat menjalankan hak dan otonominya di luar batas-batas wilayah daerah yang bersangkutan; ketiga daerah tidak boleh mencampuri hak mengatur dan mengurus rumah tangga daerah lain sesuai dengan wewenang pangkal dan urusan yang diserahkan kepadanya; dan keempat, otonomi tidak membawahi daerah lain (Yusdianto, 2015). Hal tersebut memicu diluncurkanlah regulasi mengenai Otonomi daerah, dengan harapan memberikan dasar hukum yang jelas dalam perjalanan suatu pemeritahan daerah.

Pemerintah daerah dalam rangka meningkatkan efisiensi dan efektifitas penyelenggaraan otonomi daerah perlu memperhatikan hubungan antar susunan pemerintahan dan antar pemerintahan daerah, potensi, dan keanekaragaman daerah. Aspek hubungan wewenang memperhatikan kekhususan dan keragaman daerah dalam sistem Negara Kesatuan Republik Indonesia. Aspek hubungan keuangan, pelayanan umum, pemanfaatan sumber daya alam dan sumber daya lainnya dilaksanakan secara adil dan selaras (Makhfudz, 2012). Salah satu aspek utama dalam pengembangan daerah adalah pemanfaat sumberdaya alam yang ada di suatu daerah, yang mana pemanfaatan tersebut dijadikan suatu daya tarik dalam proses pengembangan potensi yang dimiliki suatu daerah, yang nantinya mampu dikembangkan menjadi sebuah tempat wisata yang memberikan dampak yang positif bagi daerah itu sendiri.

Sektor pariwisata merupakam sebagai salah satu sektor pembangunan yang dapat memacu pertumbuhan ekonomi suatu wilayah (Soemardjan, 1977: 58), periwisata dianggap sebagai suatu aset yang strategis untuk mendorong pembangunan pada wilayah wilayah tertentu yang mempunyai potensi objek wisata. Dengan adanya perkembangan industri pariwisata di suatu wilayah, arus urbanisasi ke kota - kota besar dapat lebih ditekan. Hal ini disebabkan pariwisata memiliki tiga aspek pengaruh yaitu aspek ekonomis (sumber devisa, pajak - pajak), aspek sosial (penciptaan lapangan kerja) dan aspek budaya (Hartono, 1974 : 45). Keberadaan sektor pariwisata tersebut seharusnya memperoleh dukungan dari semua pihak seperti pemerintah daerah sebagai pengelola, masyarakat yang berada di lokasi objek wisata serta partisipasi pihak swasta sebagai pengembang. Selain peran yang dimilikinya, pariwisata juga merupakan suatu sektor yang tidak jauh berbeda dengan sektor ekonomi yang lain yaitu dalam proses perkembangannya juga mempunyai dampak atau pengaruh dibidang sosial dan ekonomi.

Setiap daerah ditantang untuk berfikir kreatif dalam penetuan langkah kebijakan demi membangun kehidupan di daerahnya. Jelas digambarkan bahwa di Indonesia daerah menjadi pengerak pembangunan nasional. Salah satu penunjang keberhasilan otonomi daerah adalah sejauh mana pemerintah mengoptimalisasikan dan mengembangkan potensi daerah yang ada. Pemda dituntut untuk professional, pandai dan juga arief dengan harapan segala kebijakan yang diambil (Fikhan, 2008:2). Pemda dalam Pengoptimalisasian potensi suatu daerah memetakan potensi dalam tiap-tiap daerah untuk dapat menetapkan dan meberikan gambaran keunggulan suatu daerah yang akan dikembangkan sebagai wisata yang nanti diharapkan dapat meningkatkan pembangunan ekonomi suatu daerah dan mampu mensejahterakan rakyat sesuai dengan tujuan suatu negara.

Tujuan dari dibuatnya negara beserta lembaga-lembaga negaranya tidak lain adalah untuk menyejahterakan rakyat di negara tersebut, seperti Negara Indonesia. Tujuan dari Negara Indonesia termaktub dalam UUD 1945 pada alenia ke-4 yaitu (1) melindungi segenap Bangsa Indonesia dan tumpah darah Indonesia, (2) memajukan kesejahteraan umum, (3) mencerdaskan kehidupan bangsa,(4) ikut melaksanakan ketertiban dunia. Hal ini menunjukkan bahwa Pemerintahan Negara Indonesia dalam setiap tindakan, kebijakan, maupun peraturan harus dilakukan dalam rangka meningkatkan kesejahteraan Bangsa Indonesia. Menurut Kamus Besar Bahasa 
Indonesia (KBBI), dalam istilah umum kesejahteraan menunjukkan pada keadaan yang baik, dan masyarakatnya berkeadaan makmur, serta dalam keadaan sehat dan damai. Guna mencapai hal tersebut pemerintah perlu melakukan tindakan tindakan pembangunan supaya kesejahteraan masyarakat dapat dicapai, salah satunya dengan pembangunan ekonomi.

Menurut Todaro (2011,16), Pembangunan ekonomi adalah upaya mencapai tingkat pertumbuhan pendapatan per kapita (income per capita) yang berkelanjutan agar negara dapat memperbanyak output yang lebih cepat dibandingkan laju pertumbuhan penduduk. Tingkat dan laju pertumbuhan pendapatan nasional bruto (gross national income - GNI) per kapita "riil" (pertumbuhan moneter dari GNI per kapita dikurangi tingkat inflasi) sering digunakan untuk mengukur kesejahteraan ekonomi penduduk keseluruhan seberapa banyak barang dan jasa riil yang tersedia untuk dikonsumsi dan diinvestasikan oleh rata-rata penduduk. Pembangunan ekonomi ini dapat dikatakan sebagai tindakan yang dilakukan oleh pemerintah dalam rangka meningkatkan kesejahteraan masyarakat dibidang ekonomi. Pembangunan ekonomi ini dapat memperkecil ketimpangan pembagian pendapatan yang terjadi dimasyarakat sehingga kemakmuran masyarakat dapat merata (Nina 2011:1). Pembangunan ekonomi perlu dilakukan setiap daerah untuk meminimalisir perbedaan pendapatan yang terjadi di masyarakat dalam rangka meningkatkan kesejahteraan masyarakat. Tingkat kesejahteraan ekonomi masyarakat yang tinggi merupakan tujuan yang ingin dicapai oleh setiap daerah. Namun manfaat tersebut harus juga dirasakan oleh seluruh lapisan masyarakat. Dengan kata lain, aspek pemerataan juga menjadi pertimbangan penting dalam keberhasilan pembangunan ekonomi di Indonesia.

Kabupaten Malang merupakan salah satu kabupaten yang ada di Provinsi Jawa Timur yang memiliki sumber daya alam yang eksotik. Eksotika alam Kabupaten Malang ditunjang dengan keindahan kawasan pegunungan dan pertaniannya. Kabupaten Malang juga memiliki potensi kebudayaan yang beragam dan unik. Potensi ini ditunjang juga dengan benda-benda bersejarah peninggalan zaman Kerajaan Singosari. Hal ini tentu akan menarik datangnya wisatawan baik domestic maupun mancanegara. Atas dasar potensi wisata yang ada, Pemerintah Kabupaten Malang menjadikan sektor pariwisata sebagai salah satu prioritas kebijakan dalam RPJMD tahun 2016-2021. Kebijakan Umum Pembangunan Kabupaten Malang 20162021 disusun sebagai tahap operasional dari upaya untuk mencapai Visi dan Misi Kabupaten Malang selama lima tahun ke depan yang menggambarkan keterkaitan antara bidang urusan pemerintahan daerah dengan rumusan indikator kinerja sasaran yang menjadi acuan penyusunan program pembangunan jangka menengah daerah VII-2 berdasarkan strategi dan arah kebijakan yang ditetapkan. Salah satu misi dalam program pembangunan tersebut adalah Mengembangkan ekonomi masyarakat berbasis pertanian, pariwisata, dan industri kreatif dengan tujuan: Meningkatkan perekonomian masyarakat. Kebijakan Kabupaten Malang tersebut erat kaitannya dengan pembangunan ekonomi yaitu 1. Pengembangan branding destinasi wisata Kabupaten Malang; 2. Memaksimalkan potensi wisata berbasis lingkungan hidup (Ekowisata); 3 . Pengembangan wisata berbasis budaya dan kearifan local.

Hal tersebut dilakukan dengan menggerakkan potensi pertanian di wilayah Kabupaten Malang yang beraneka ragam dan tersebar di seluruh kecamatan. Bidang pertanian unggulan meliputi tanaman pangan, perkebunan, sayuran, peternakan dan perikanan. Terdapat komoditas khas Kabupaten Malang yaitu: apel, Jeruk, klengkeng, salak Swaru, ketela gunung kawi. Komoditas tersebut dapat dijadikan sebagai daya dukung kabupaten malang dalam mencapai misinya. Dalam rangka mewujudkan program pembangunan tersebut, maka strategi yang ideal yaitu melalui optimalisasi potensi desa, yang mana tiap-tiap desa dituntut untuk memaksimalkan potensi yang ada agar dapat menghasilkan daya tarik wisata. Daya tarik wisata yang dimaksud adalah hasil dari potensi yang dimiliki oleh suatu desa.

Pemerintah Kabupaten Malang dibawah komando Dr. Rendra Kresna terus mengangkat potensi-potensi desa lewat pemetaan potensi desa (Kompas). Salah satu daerah yang memiliki sumber potensi alam adalah Desa Donowarih yang terletak di kecamatan Karangploso, kabupaten Malang. Mayoritas penduduknya berpencaharian sebagai petani dan peternak 
karena sebagaian besar lahan yang ada di desa Donowarih didominasi perkebunan dan masyarakat setempat lebih memilih mengembangkan usahanya dari hasil perkebunan dan peternakan. Namun, potensi alam yang paling menonjol di desa Donowarih ini ialah perekebuann jeruk yang menjadi daya tarik tersendiri oleh masyarakat desa Donowarih. Potensi kebun jeruk di Donowarih sangat besar. Menurut Bapak Joko selaku Kepala Desa Donowarih, Desa Donowarih tepatnya di Dusun Borogragal memiliki potensi yang besar diantaranya luas lahan perkebunan jeruk kurang lebih seluas 50 hektar dan setiap tahunnya panen jeruk Dusun Borogragal per pohon dapat menghasilkan 1-2 kwintal danakumulasi panenjeruk Dusun Borogragal 700 ton. Hal inilah yang memunculkan ide dari pemerintah daerah Kabupaten Malang untuk menjadikan sebuah objek wisata petik jeruk.

Wisata petik jeruk merupakan program optimalisasi pariwisata di Kabupaten Malang yang tertuang dalam RPJMD Kabupaten Malang. Wisata petik jeruk ini telah diluncurkan Pemerintah Kabupaten Malang oleh Dr. Rendra Kresna pada hari Jum'at 14 April 2017. Wisata petik jeruk ini terletak di Dusun Borogragal, Desa Donowarih, Kecamatan Karangploso, Kabupaten Malang. Wisata petik jeruk ini akan menjadi daya tarik guna meningkatkan kesejahteraan masyarakat. Namun besarnya potensi yang dimiliki Desa Donowarih tidak dibarengi dengan pengadaan ladasan hukum yang jelas untuk mengatur wisata petik jeruk ini. Menurut Bapak Joko landasan hukum mengenai wisata petik jeruk ini belum ada dalam pemerintahan Desa Denowarih.

Mengenai kesiapan untuk mengoptimalisasikan Wisata Petik jeruk tersebut dari masyarakat telah meberikan apresiasi kesipaan untuk mengoptimalakan wisata petik jeruk. sementara itu, pemerintah desa juga telah membangun infrastruktur yang saat ini proses pengerjaanya sedang berlangsung untuk menjadikan wisata petik jeruk lebih maju dan berinovatif. Menurut Kepala Desa Donowarih Bapak Joko, beliau telah merencanakan beberapa gagasan mengenai pembangunan yang berhubungan dengan optimalisasi desa wisata yaitu gagasan bahwa rest area. Hal ini sesuai dengan target RPJM wisata petik jeruk. Secara berkesinambungan pemerintah dam masyarakat membentuk sebuah hubungan untuk mewujudkan wisata petik jeruk melalui modal sosial yang mampu mmeberikan arahan dan bentuk antara keduanya dalam mensuskseskan wisata petik jeruk.

Modal sosial merupakan suatu rangkaian proses hubungan antar manusia yang ditopang oleh jaringan, norma-norma dan kepercayaan sosial yang memungkinkan efisiensi dan efektifitas koordinasi dan kerjasama untuk keuntungan bersama, lebih menekankan pada dimensi yang lebih luas yaitu segala sesuatu yang membuat masyarakat bersekutu untuk mencapai tujuan bersama atas dasar kebersamaan dan didalamnya diikat dengan nilai-nilai dan norma-norma yang tumbuh dan dipatuhi (Thobias, 2013). Modal sosial ini dikaitkan dengan nilai dan norma yang akan menjadi sebuah kekuatan dalam menghasilkan kapasitas adaptasi masyarakat pedesaan dalam pengelolaan dan pembangunan infrastruktur.

Kapasitas adaptasi ini berupa kerjasama, partisipasi semua elemen masyarakat, pemanfaatan teknologi yang sesuai dengan kebutuhan masyarakat, prinsip saling menjaga, dan kemampauan memobilisasi sumberdaya kolektif dalam anggota kelompok (Kusumastuti, 2015). Modal sosial berperan penting dalam proses pembangunan ekonomi suatu daerah karena modal sosial sebagai alokasi sumberdaya yang menjadi aset di setiap daerah, sehingga partisipasi masyarakat desa terlihat jelas ketika pemerintah daerah dan masyarakat desa Donowarih saling bekerjasama dalam mewujudkan wisata petik jeruk, dengan adanya modal sosial ini diharapkan proses pembangunan wisata petik jeruk lebih efektif, sehingga dapat memicu Modal sosial dapat memicu pembangunan dan pengelolaan sumberdaya desa Donowarih. Atas dasar latar belakang tersebut peneliti tertari untuk melakukan penelitian dengan judul "ANALISIS MODAL SOSIAL UNTUK KESEJAHTERAAN MASYARAKAT LOKAL (Studi Pada Wisata Petik Jeruk Di Dusun Borogragal, Desa Donowarih, Kecamatan Karangploso, Kabupaten Malang)"

\section{Tinjauan Pustaka}

\section{Modal Sosial}

Modal social adalah bentukan dari hubungan yang lebih menekankan pada nilai-nilai kebersamaan dan kepercayaan baik dalam suatu 
komunitas maupun antar komunitas. Nilai-nilai tersebut merupakan suatu modal dalam membentuk masyarakat yang kuat dan berkepribadian, dimana saat ini sangat penting karena ketika suatu komunitas atau masyarakat dihadapi dengan suatu masalah maka akan cepat diatasi tanpa harus ada yang dirugikan. (Suryono, 2012)

Modal social dibentuk oleh beberapa elemen, diantaranya oleh Pantoja dalam Agus Suryono (2012) mengindentifikasi modal social menjadi enam elemen, yaitu keluarga dan kerabat, kehidupan asosiasi yang bersifat horizontal (kelompok), jaringan social, masyarakat politik, institusi, dan norma atau nilai-nilai social.

Elemen-elemen modal social tersebut akan menjadi sumber munculnya interaksi antara orang-orang dalam satu komunitas. Hasil dari interaksi tersebut menjadi parameter pengukuran modal social, seperti tercipta dan terpeliharanya kepercayaan antar warga masyarakat. Selain itu, interaksi tersebut dapat terjadi dalam skala individual maupuninstitusional.Secara individual, interaksi yang terjadi melalui hubungan antar individu kemudian akan melahirkan ikatan emosional antara dua individu maupun dalam kelompok. Secara institusional, interaksi dapat lahir pada saat tujuan suatu organisasi memiliki kesamaan dengan organisasi lainnya. Untuk mengukur interaksi tersebut, ada tiga parameter modal social yang dapat digunakan, yaitu:

1. Kepercayaan (trust)

Kepercayaan merupakan nilai yang ditunjukan oleh adanya perilaku jujur, teratur dan kerja sama berdasarkan normanorma yang dianut bersama. Pada dasarnya kepercayaan harus dimiliki dan menjadi bagian yang kuat untuk membentuk modal social yang baik, yang dapat ditandai dengan kuatnya lembaga-lembaga social yang menciptakan kehidupan yang harmonis dan dinamis. Hasbullah (2006) dalam Agus Suryono (2012) berpendapat bahwa berbagai tindakan kolektif yang didasari atas rasa saling mempercayai yang tinggi akan meningkatkan partisipasi dalam berbagai ragam bentuk dan dimensi terutama dalam konteks membangun kemajuan bersama. Masyarakat yang kurang memiliki perasaan saling mempercayai akan sulit menghindari berbagai situasi kerawanan social dan ekonomi yang mengancam.
Semangat kolektifitas tenggelam dan partisipasi masyarakat untuk membangun bagi kepentingan kehidupan yang lebih baik akan hilang. Lambat laun akan mendatangkan biaya tinggi bagi pembangunan karena masyarakat cenderung bersikap apatis dan hanya mempercayai telah luntur maka yang akan terjadi adalah sikap yang menyimpang dari norma dan nilai yang berlaku.

2. Norma (norms)

Norma merupakan susunan dari pemahaman terhadap nilai-nilai kehidupan serta harapan yang diyakini dan dijalankan oleh sekelompok orang. Norma yang terbentuk dapat didasari oleh nilai-nilai agama, nilainilai budaya, maupun nilai-nilai dari kehidupan sehari-hari yang dibuat menjadi aturan-aturan untuk ketertiban kehidupan berbangsa dan bernegara. Norma juga merupakan modal social karena muncul dari kerjasama di masa lalu yang kemudian diterapkan untuk kehidupan bersama. Norma-norma social akan sangat berperan dalam mengontrol bentuk-bentuk perilaku yang tumbuh dalam masyarakat.

Hasbullah (2006) dalam Agus Suryono (2012) memberikan pengertian norma itu sendiri sebagai sekumpulan aturan yang diharapkan dipatuhi dan diikuti oleh anggota masyarakat pada suatu entitas social tertentu. Norma-norma tersebut terinstitusional dan mengandung sangsi social yang dapat mencegah individu berbuat sesuatu yang menyimpang dari kebiasaan yang berlaku di masyarakatnya. Aturan-aturan kolektif tersebut biasanya tidak tertulis tapi dipahami oleh setiap anggota masyarakatnya dan menentukan pola tingkah laku yang diharapkan dalam konteks hubungan social. Aturan-aturan kolektif yang biasanya muncul pada masyarakat dapat berupa bagaimana menghormati orang yang lebih tua, menghormati pendapat orang lain, norma untuk hidup sehat, norma untuk tidak mencurigai orang lain, norma untuk selalu bersama-sama dan banyak lagi aturan-aturan yang secara tidak langsung telah disepakati oleh kelompok masyarakat tertentu.

3. Jaringan-jaringan (networks).

Jaringan (kelompok dan jaringan social) merupakan bentukan dari infrastruktur 
90 | Rini Puji Lestari, dkk., Analisis Modal Sosial untuk Kesejahteraan Masyarakat Lokal

modal social itu sendiri. Jaringan tersebut menjadi fasilitator dalam mendukung terjadinya interaksi yang kemudian akan menumbuhkan kepercayaan dan kerja sama yang kuat. Semakin kuat jaringan social yang terbentuk maka akan semakin kuat pula kerja sama yang ada didalamnya dan selanjutnya akan memperkuat modal social yang terbentuk. Modal social tidak dibangun hanya oleh satu individu, melainkan akan terletak pada individu-individu yang tumbuh dalam suatu kelompok untuk bersosialisasi sebagai bagian penting dari nilai-nilai yang melekat. Modal social yang ada akan tergantung pada kapasitas yang ada dalam kelompok masyarakat untuk membangun sejumlah asosiasi beserta jaringannya yang tujuan adalam untuk menciptakan hubungan social.

Menurut hasbullah (2006) dalam Agus Suryono (2012) masyarakat selalu berhubungan social dengan masyarakat lain melalui berbagai variasi hubungan yang saling berdampingan dan dilakukan atas prinsip sukarela (voluntary), kesamaan (equality), kebebasan (freedom), dan keadaban (civility), kemampuan anggota-anggota kelompok/ masyarakat untuk selalu menyatukan diri dalam suatu pola hubungan yang sinergi, akan sangat besar pengaruhnya dalam menentukan kuat tidaknya modal social suatu kelompok. Dalam hal ini jaringan social tentunya memiliki peran yang penting. Jaringan hubungan social biasanya akan diwarnai oleh suatu tipologi tertentu yang sejalan dengan karateristik dan orientasi kelompok. Pada kelompok social, yang biasanya terbentuk secara tradisional atas dasar kesamaan garis keturunan, pengalaman-pengalaman social turun temurun, dan kesamaan kepercayaan pada dimensi ketuhanan cenderung memiliki kohensifitas tinggi, tetapi rentang jaringan maupun kepercayaan yang terbentuk sangat sempit.

\section{Metode Penelitian}

Jenis penelitian yang digunakan dalam penelitian ini adalah penelitian deskriptif dengan pendekatan kualitatif yang bertujuan untuk menggambarkan dan menganalisis modal sosial untuk kesejahteraan masyarakat lokal pada
Wisata Petik Jeruk di Dusun Borogragal, Desa Donowarih, Kecamatan Karangploso, Kabupaten Malang. Fokus dalam penelitian ini adalah sebagai berikut:

(1) Network(jaringan),

(2) Trust (percaya),

(3) Social norms (norma sosial),

Lokasi dalam penelitian ini adalah berada pada Kabupaten Malang. Situs penelitian mengambil tempat pada Dusun Borogragal Desa Donowarih, Kab. Malang.

Data primer dalam penelitian ini bersumber dari hasil wawancara terhadap informan yakni :

1. BapakSujoko selaku Kepala Desa Donowarih

2. Bapak Ari selaku Sekretaris Desa Donowarih

3. Bapak Sampir dan Ibu Tasriah selaku Petani

Jeruk di Desa Donowarih

Adapun data sekunder diperoleh dari arsiparsip, artikel maupun dokumen.

Pengumpulan data dilakukan dengan cara; (1) observasi; (2) wawancara; (3) dokumentasi. Instrumen penelitian ini adalah peneliti, interview guide, alat perekam, alat komunikasi, dan buku catatan. Teknik analisis data dalam penelitian ini menggunakan teknik analisis John W. Creswell. Adapun tahap tahap analisis yang digunakan dala teknik analisis John W. Creswell yakni ; Mengolah dan mempersiapkan data; membaca keseluruhan data; menganalisis lebih detail dengan meng-coding data; menerapkan proses koding untuk mendeskripsikan setting, orangorang-, kategori-kategori, dan tema-temayang dianalisis; menunjukkan bagaimana deskripsi dan tema-tema ini akan disajikan kembali dalam narasi/laporan kualitatif; dan menginterpretasi atau memaknai data.

\section{Hasil dan Pembahasan}

\section{Profil Desa Donowarih}

Desa Donowarih adalah salah satu Desa yang berada di Kecamatan Karangploso Kabupaten Malang Propinsi Jawa Timur. Desa Donowarih terletak di sebelah selatan kaki Gunung Arjuna bahkan sebagian dusunnya berada di lereng gunung, Topografi berupa dataran dan perbukitan serta berada pada ketinggian 600 sampai dengan $850 \mathrm{~m}$ dari permukaan air laut sehingga mengakibatkan desa ini berhawa sejuk dan dingin.Desa Donowarih berbatasan dengan Desa Bocek dan Hutan Lindung (batas utara), Desa Girimoyo dan Desa Bocek (batas timur), 
Desa Pendem (batas selatan), Desa Tawangargo (batas barat).

Desa Donowarih memiliki luas wilayah $1.298,018$ ha, yang dimanfaatkan sebagai lahan untuk pemukiman, lahan persawahan, ladang, perkebunan, hutan dan lain-lain. Desa Donowarih termasuk mempunyai tanah yang subur untuk usaha pertanian sehingga masyarakat sebagian besar mempunyai usaha pertanian sayur-mayur, padi, jagung, tanaman buah buahan (apel, jeruk), kopi, tebu pada lahan basah dan kering.

Dengan potensi topografi dataran, perbukitan di dukung dengan hijauanya tanaman dan pepohonan bila dipandang dari ketinggian gunung mujur merupakan panorama yang menarik bagi siapa saja yang berkunjung, dengan kehidupan masyarakat yang sederhana dan ramah, selain itu ada juga tempat bermain yang sejuk dan menarik dilengkapi kolam renang, lapangan tenes yang dapat dikunjungi masyarakat umum terdapat di area perumahan Argokencana.

\section{Modal Sosial Wisata Petik Jeruk di Desa Donowarih}

\section{Network (jaringan)}

Jaringan social menjadi fasilitator dalam mendukung terjadinya interaksi yang kemudian akan menumbuhkan kepercayaan dan kerja sama yang kuat. Semakin kuat jaringan social yang terbentuk maka akan semakin kuat pula kerja sama yang ada di dalamnya dan selanjutnya akan memperkuat modal social yang terbentuk. Menurut hasbullah (2006) dalam Agus Suryono (2012) masyarakat selalu berhubungan social dengan masyarakat lain melalui berbagai variasi hubungan yang saling berdampingan dan dilakukan atas prinsip sukarela (voluntary), kesamaan (equality), kebebasan (freedom), dan keadaban (civility), kemampuan anggotaanggota kelompok/ masyarakat untuk selalu menyatukan diri dalam suatu pola hubungan yang sinergi, akan sangat besar pengaruhnya dalam menentukan kuat tidaknya modal social suatu kelompok.

Apabila dihubungkan dengan wisata petik jeruk di Desa Donowarih, jaringan atau jalinan kerja sama dengan stakeholder menjadi penting untuk mendukung berkembangnya wisata petik jeruk. Dalam hal ini stakeholder yang berperan penting adalah Dinas Pariwisata. Namun selama ini peran dari Dinas Pariwisata masih belum terasa atau masih belum optimal dalam keikutsertaannya mendukung wisata petik jeruk. Hal ini terlihat dari belum nampaknya pendidikan dan pelatihan yang diberikan kepada pemerintah desa atau petani jeruk terkait dengan pengembangan wisata petik jeruk. Kurangnya partisipasi dari dinas tentunya akan berpengaruh yang signifikan terhadap pengembangan wisata petik jeruk. Pemerintah desa dan petani jeruk yang minim pengalaman dan pengetahuan dalam pengembang wisata masih membutuhkan bantuan, dukunagn, dan bimbingan dari dinas pariwisata.

Pemerintah kabupaten malang telah membentuk kelompok sadar wisata atau disingkat Pokdarwis yang anggotannya adalah masayarkat yang memiliki kepedulian kepada wisata daerah. Adanya kelompok ini diharapkan dapat memberikan membantu jalannya pengembangan wisata petik jeruk. Namun dalam pembentukan kelompok sadar wisata di desa donowarih masih belum bisa terwujud dan selama ini hanya menunggu sosialisasi yang diberikan oleh pokdarwis dari pemkab malang. Adanya sosialiasi itu pun juga dirasa belum menghasilkan output yang maksimal. Untuk mengatasi hal ini tentunya diperlukan koordinasi antara pemerintah kabupaten Malang dengan pemerintah desa Donowarih. Selama berjalannnya wisata petik jeruk di desa Donowarih ini. Hubungan atau komunikasi atau koordinasi antara pemkab dengan pemdes masih belum efektif, kegiatan yang dilakukan juga belum maksimal. Hubungan yang demikian akan menghambat proses pengembangan dari wisata petik jeruk.

Jaringan yang dimiliki Desa Donowarih dengan desa-desa lain sangat potensial dalam mendukung pengembangan wisata petik jeruk. Jaringan dengan Desa Selokerto dan sembilan desa di Kecamatan Karangploso menjadi modal Desa Donowarih dalam mengembangkan wisata petik jeruk. Modal tersebut memang bukan dalam bentuk material tapi modal dalam bentuk pengetahuan dan skema wisata yang menjadi lebih penting dalam pengembangan wisata petik jeruk. 


\section{Trust (kepercayaan)}

Kepercayaan merupakan sifat yang didasarkan pada keyakinan yang mendalam terhadap sesuatu hal yang dipercayai. Kepercayaan yang kuat akan menjadi modal utama dalam pembentukan modal sosial dimasyarakat. Menurut Hasbullah (2006) dalam Agus Suryono (2012) berbagai tindakan kolektif yang didasari atas rasa saling mempercayai yang tinggi akan meningkatkan partisipasi dalam berbagai ragam bentuk dan dimensi terutama dalam konteks membangun kemajuan bersama. Perasaan mempercayai akan menumbuhkan rasa keinginan untuk ikut serta dalam proses pembangunan. Sebaliknya masyarakat yang kurang memiliki perasaan saling mempercayai akan sulit menghindari berbagai situasi kerawanan sosial dan ekonomi yang mengancam. Lebih jauh lagi masyarakat yang kurang memliki rasa percaya satu sama lain akan menumbuhkan sifat apatis yang dapat menimbulkan sifatsifat yang menyimpang dari norma dan nilai yang ada yang berakibat pada terhambatnya proses pembangunan dimasyarakat. Pembuatan wisata petik jeruk disambut dengan antusias oleh masyarakat Desa Donowarih dan juga masyarakat sangat senang dengan adanya wisata petik jeruk ini. Masyarakat Desa Donowarih berpendapat bahwa wisata petik jeruk ini akan memberikan hal yang positif kepada mereka. Selain itu, Wisata petik jeruk ini dalam proses pembuatannya tidak mendapatkan penolakan dari warga sama sekali bahkan seluruh warga menyetujui dengan adanya wisata petik jeruk ini. Namun diawal pembuatannya pernah terjadi pro dan konta yang terjadi di perangkat Desa Donowarih tetapi akhirnya para perangkat desa yang mulanya tidak setuju kini telah menyetujuinya. Hal ini menunjukan bahwa masyarakat Desa Donowarih telah memiliki partisipasi yang tinggi dalam proses pembuatan wisata petik jeruk ini. hal tersebut mengidikasikan bahwa masyarakat Desa Donowarih memiliki rasa percaya dengan dibangunnya wisata petik jeruk ini.

Kepercayaan yang didapatkan secara umum dalam penelitian ini belum sampai pada kepercayaan antar masyarakat dalam mengembangkan wisata petik jeruk di Desa Donowarih. Kepercayaan yang didapatkan dalam penelitian ini baru sebatas kepercayaan masyarakat kepada wisata petik jeruk untuk meningkatkan perekonomian mereka.

\section{Norms (norma)}

Menurut Hasbullah (2006) dalam Agus Suryono (2012) memberikan pengertian norma itu sendiri sebagai sekumpulan aturan yang diharapkan dipatuhi dan diikuti oleh anggota masyarakat pada suatu entitas social tertentu. Terbentuknya suatu norma di masyarakat bertujuan untuk mengontrol bentuk-bentuk perilaku yang tumbuh dalam masyarakat. Pada Wisata Petik Jeruk di Desa Donowarih belum terdapat landasan hukum dari pemerintah desa. Sejauh ini peraturan-peraturan yang ada terkait wisata petik jeruk ialah tentang pembagian hasil dan teknis pada wisata petik jeruk, akan tetapi peraturan tersebut bukan merupakan peraturan tertulis peraturan yang diterapkan saat ini hanya peraturan yang tidak tertulis yang diyakini oleh para petani. Hal-hal tersebut mengakibatkan belum adanya perkembangan yang signifikan terhadap wisata petik jeruk selama 3 tahun masa percobaan ini. Regulasi yang tidak dikeluarkan oleh pemerintah desa mengakibatkan arah perkembangan wisata petik jeruk tersebut yang belum jelas akan diarahkan kemana.

Pengembangan wisata petik jeruk di Desa Donowarih dalam berjalannya nanti memiliki peraturan yang tidak tertulis dimana petani jeruk dihimbau untuk menyewa lahan wisata petik jeruk. Penyewaan lahan bertujuan untuk mendorong masyarakat dalam berkontribusi didalam pengembangan wisata petik jeruk. Sistem bagi hasil tersebut nantinya dari keuntungan yang didapat akan dibagi untuk petani dan ke kas desa. Petani yang tidak menyewa lahan wisata petik jeruk maka dianggap tidak memberikan kontribusi kepada kas desa. Norma tentang sewa menyewa lahan wisata petik jeruk merupakan modal sosial yang dapat mendorong partisipasi masyarakat dalam melakukan pembangunan di desa. Hal tersebut membuat petani merasa memiliki program yang telah ditetapkan 
sehingga dapat mendukung keberhasilan program. Lebih lanjut peneliti belum bisa menemukan norma-norma yang lahir atas dasar interaksi masyarakat yang mendorong pengembangan wisata petik jeruk Desa Donowarih.

\section{Faktor Pendukung}

Wisata Petik Jeruk merupakan gagasan dari Kepala Desa Donowarih untuk menyukseskan salah satu program Kabupaten Malang yaitu optimalisasi potensi desa. Wisata petik jeruk ini digagaskan oleh Kepala Desa Donowarih dikarenakan potesi yang besar di Desa Donowarih khususnya dalam bidang pertanian jeruk. Wisata petik jeruk ini dalam pelaksanaannya terdapat beberapa faktor yang mendukung jalannya realisasi wisata petik jeruk.

Wisata petik jeruk di Desa Donowarih ini dalam setiap pelaksanaannya kegiatanya selalu mendapatkan dukungan dari masyarakat sekitar. Masyarakat yang mendukung setiap kegiatan wisata petik jeruk ini akan meperlancar realisasi wisata petik jeruk ini karena dalam pembentukannya tidak akan banyak terjadi gesekan-gesekan antara pihak yang pro. Motivasi yang tinggi dari perangkat desa juga akan memberikan dampak yang besar bagi jalannya realisasi wisata petik jeruk. kuatnya motivasi perangkat Desa Donowarih disebabkan wisata petik jeruk sudah masuk pada Rencana Pembangunan Jangka Menengah Desa. Kedua hal tersebut yang menjadi faktor yang kuat dalam kelancaran realisasi wisata petik jeruk di Desa Donowarih.

Selain kedua faktor diatas antusiasme warga sektiar yang tinggi dalam merespon setiap kebijakan juga menjadi faktor yang memperlancar program Wisata petik jeruk di Desa Donowarih ini. partisipasi yang tinggi masyarakat disetiap kebijakan yang dikeluarkan oleh perangkat desa menandakan bahwa kepercayaan masyarakat yang tinggi pula terhadap perangkat desa sehingga bisa menurunkan bahkan menuadakan tindakan tindakan yang berlawanan dengan peraturan perangkat desa yang akan memperlambat terrealisasinya program wisata petik jeruk.

Skema wisata petik jeruk yang memiliki tidak hanya satu destinasi wisata yaitu wisata petik jeruk itu sendiri dan Wisata Religi Gunung Mujur. Pembuatan skema wisata petik jeruk menunjukan bahwa keseriusan perangkat desa untuk membetuk sebuah program peningkatan ekonomi masyarakat dengan potensi Desa Donowarih yang besar. Selain itu, pengembangan wisata petik jeruk desa donowarih juga didukung oleh kebijakan Bupati Kabupaten Malang melalui program optimalisasi pariwisata yang berbasis potensi desa

\section{Faktor Penghambat}

Wisata Petik Jeruk pada Desa Donowarih merupakan desa wisata yang digagas untuk menyukseskan salah satu program di Kabupaten Malang yaitu program optimalisasi potensi desa, namun selain itu wisata petik jeruk juga digagas oleh kepala desa donowarih karena besarnya potensi yang dimiliki desa donowarih pada perkebunan jeruk. Akan tetapi terhambatnya wisata petik jeruk juga disebabkan oleh beberapa factor penghambat pembangunan wisata petik jeruk baik secara internal maupun eksternal. Adapun faktor penghambat pada wisata petik jeruk di desa Donowarih disebabkan oleh beberapa aktor yaitu pemerintah desa itu sendiri dan dinas-dinas terkait.

Faktor penghambat yang menyebabkan tidak berjalannya wisata petik jeruk didesa donowarih kabupaten malang ini ialah karena belum adanya regulasi atau peraturan daerah yang dimiliki desa Donowarih terkait wisata petik jeruk. Hal ini mengakibatkan pembangunan yang dijalani wisata petik jeruk belum memiliki landasan yang kuat. Selain belum adanya regulasi yang dimiliki ialah belum maksimalnya peran dari dinas-dinas terkait untuk membantu menyukseskan wisata petik jeruk tersebut. Selama ini peran dinas-dinas terkait yang diberikan ialah berupa sosialisasi untuk POKDARWIS atau Kelompok Sadar Wisata yang mana pada sosialisasi tersebut diminta untuk seluruh desa mengirimkan delegasi untuk mengikuti sosialisasi tersebut, tetapi masih hanya sebatas sosialisasi tersebut.

Selanjutnya ialah terkait konsep wisata petik jeruk itu sendiri yang belum matang dari pemerintah desa. Saat ini pemerintah desa Donowarih masih belum menemukan solusi terkait bagaimana wisata petik jeruk tersebut agar tetap jalan pada saat tidak musim panen, karena selain wisata petik jeruk Desa Donowarih juga memiliki objek wisata lain yaitu wisata religi, akan tetapi hal ini masih berupa gagasan 
dari kepala desa Donowarih. Selain itu ialah faktor kapasitas sumber daya manusia desa yang kurang kapabilitas dalam mengembangkan wisata petik jeruk. Masalah kapasitas sumber daya manusia dalam mengembangkan desa menjadi masalah yang banyak dihadapi oleh desa dalam melakukan pembangunan. Pada pengelolaan wisata petik jeruk di desa Donowarih masih berpatokan pada masyarakat yang telah berhasil menghasilkan jeruk dengan jumlah yang banyak dan kualitas yang baik yang dilakukan secara turun temurun.

Beberapa fackor penghambat pada modal social yang dimiliki dalam masyarakat wisata petik jeruk Desa Donowarih ialah belum adanya regulasi atau peraturan daerah yang dimiliki desa Donowarih terkait wisata petik jeruk serta belum maksimalnya peran dari dinas-dinas terkait untuk membantu menyukseskan wisata petik jeruk tersebut, selain itu juga konsep terkait wisata petik jeruk itu sendiri yang belum matang dari pemerintah desa.

\section{Simpulan}

Wisata petik jeruk di Desa Donowarih merupakan program dari pemrintah kabupaten malang mengenai pembangunan yang berorientasi pada optimalisasi potensi desa. Tujuan diadakannya program wisata petik jeruk adalah untuk mensejahterakan kehidupan masyarakat desa donowarih. Pengembangan wisata petik jeruk tersebut diperlukan modal sosial untuk mendukung berjalannya program pemerintah kabupaten malang. Modal sosial merupakan faktor utama yang harus dimiliki masyarakat dalam mengoptimalkan potensi desa guna mewujudkan wisata petik jeruk yang ideal, dimana didalam modal sosial terdapat beberapa Indikator yang perlu diperhatikan. Berikut ini beberapa indikator yang harus diperhatikan dalam proses pembangunan wisata petik jeruk anatara lain : (1) Jaringan; Desa Donowari membutuhkan Dinas Pariwisata dalam mengembangkan wisata petik jeruk. Namun, selama ini dinas pariwisata masih belum berkontribusi secara maksimal terhadap wisata petik jeruk. Jaringan yang dimiliki Desa Donowarih dengan dinas-dinas belum optimal. Namun, dilihat dari jaringan kerjasama Desa Donowarih dengan desa lain menjadi modal yang potensial dalam mengembangkan wisata petik jeruk. Jaringan sosial petani yang diakomodir melalui kelompok tani dapat mendukung keberhasilan pengembangan wisata petik jeruk Desa Donowarih. (2) Kepercayaan; Pembangunan wisata petik jeruk di desa donowarih telah mendapat dukungan dari masayarakat. Dukungan tersebut terlihat dari antusias dan partisipasi masyarakat dalam pengembangan wisata petik jeruk. Hal ini mengindikasikan bahwa masyarakat telah mempercayai dan menaruh harapan pada wisata petik jeruk untuk dapat meningkatkan kesejahteraan masyarakat. Kepercayaan yang didapatkan dalam penelitian ini baru sebatas kepercayaan masyarakat kepada wisata petik jeruk untuk meningkatkan perekonomian mereka. (3) Norma; dalam pembangnan wisata petik jeruk di desa donowarih, pemerintah desa masih belum membentuk dasar hukum yang berkaitan dengan wisata petik jeruk. Walau sudah terdapat peraturan secara lisan namun hal ini kurang menguatkan perkembangan wisata petik jeruk sediri, karena dasar hukum lah yang sangat memuat teknik wisata petik jeruk. Himbauan petani untuk menyewa lahan wisata petik jeruk dapat menjadi potensi norma yang dapat mendukung pengembangan wisata petik jeruk melalui partisipasi masyarakat.

\section{Saran}

Berdasarkan kesimpulan yang telah dipaparkan diatas, maka saran yang dapat diberikan adalah sebagai berikut: (a) Pemerintah desa mengambil inisiatif untuk membuka kerjasama dengan pihak swasta dan universitas untuk melakukan pengembangan dan penelitian di wisata petik jeruk desa Donowarih. (b) Masyarakat dapat memperkuat kelembagaan melalui kelompok tani dan pemerintah desa dapat segera merealisasikan pembangunan wisata petik jeruk untuk menjaga kepercayaan masyarakat (c) Pemerintah desa dapat segera membuat peraturan desa yang mengatur tentang pengembangan wisata petik jeruk. (d) Pemerintah desa dapat melakukan perencanaan pengembangan wisata petik jeruk 


\section{Daftar Pustaka}

Amanda, Helmei Willy. 2015. Strategi Pembangunan Desa Dalam Meningkatkan Pendapatan Asli Desa Melalui Badan Usaha Milik Desa (Bumdes) (Studi Pada Badan Pengelola Air Minum (Bpam) Di Desa Ketapanrame Kecamatan Trawas Kabupaten Mojokerto). Jurnal Publika, Vol.3, No.5, Thn. 2015, Hal. 7-12

Andriany, Dewi. Pengembangan Model Pendekatan Partisipatif dalam Memberdayakan Masyarakat Miskin Koita Medan untuk Memeperbaiki Taraf Hidup. Seminar Nasional Ekonomi Manajemen dan Akuntansi (SNEMA) FakultasEkonomiUniversitasNegeriPadang.

Bryant, Coralie. 1982. Managing development in the third world. Westview Press Inc. Terjemahan Rusyanto L. Simatupang. 1987. Manajemen Pembangunan Untuk Negara Berkembang. Edisi pertama. LP3ES. Jakarta

Cahyono, Budhi, dan Ardian Ardiatama. 2012. Peran Modal Sosial Dalam Peningkatan Kesejahteraan Masyarakat Petani Tembakau Di Kabupaten Wonosobo. Dalam jurnal Ekonomi Vol.1 No.1 Desember 2012

Creswell, John W. 2012. Research Design: Pendekatan Kualitatif, Kuantitatif dan Mixed. Yogyakarta: Pustaka Pelajar

Cristian, Harry. 2015. Studi tentang Pelaksanaan Rencana Kerja Pembangunan Desa (RKPDes) Tahun 2013 di Desa Loa Janan Ulu Kecamatan Loa Janan Kabupaten Kutai Kartanegara. Ejournal Pemerintah Integratif. 3 (1)

Dorani, Ahmad. 2008. Analisis Pengaruh Pelaksanaan Desentralisasi Fiskal terhadap PDRB di Kabupaten atau Kota Provinsi Jawa Tengah Tahun 2005-2008.

Erikadianarizant. 2012. Konsep Pembangunan. (online), . Diakses pada 2 Juni 2017, (14:05)

Habibi, Muhammad Mujtaba. 2015. Analisis Pelaksanaan Desentralisasi Dalam Otonomi Daerah Kota/Kabupaten. Jurnal Pendidikan Pancasila dan Kewarga negaraan, Th. 25, Nomer 2, Agustus 2015, hal.117-124
Haningtyas, Sjamsiar Sjamsuddin, dan Minto Hadi. 2014. "Peran Pemerintah dan Masyarakat dalam Upaya Pengembangan Pendidikan Nonformal (tudi Kasus: Eksistensi "Kampung Inggris" Kabupaten Kediri)". JAP: Jurnal Administrasi Publik, No 2 Vol 2, hal.264268,2014.

Harusi, Fikhan. 2008. Otonomi Daerah Di Indonesia (Studi Kasus Daerah Kota Madya Depok ). Skripsi. Fakultas Usluddin dan Filsafat, Jurusan Akidah Filsafat. UIN Syarif Hidayatullah

Hikmat, Harry. 2014. Analisis Dampak Lingkungan Sosial" Strategi Menuju Pembangunan Berpusat pada Rakyat (People Centered Development). Andalsos:Staf Ahli DampakSosial Kemensos.

Husen, Sharifuddin. 2011. Pengaruh Pengeluaran Agregat dalam Mendorong Pertumbuhan Produk Domestik Bruto dan Implikasi pada Kesejahteraan Sosial. Jurnal Ekonomi Pembangnan, Vol. 12, No. 1, Juni 2011, Hal. 130158.

Jatimtimes.com. 2017. Jeruk Keprok Donowarih Siap Ramaikan Destinasi Wisata Kabupaten Malang. (online), . Diakses pada 2 Juni 2017. (14:00)

Korten, D.C. 1993. Menuju Abad ke-21: Tindakan Sukarela dan Agenda Global

Forum Pembangunan Berpusat-Rakyat. Jakarta: Yayasan Obor Indonesia dan Pustaka Sinar Harapan.

Kusumastuti, Ayu. 2015. Modal Sosial dan Mekanisme Adaptasi Masyarakat Pedesaan dalam Pengelolaan dan Pembangunan Infrastruktur. Jurnal Sosiologi, Vol 20, No. 1, Januari 2015, hal 81-97

Momuat, MMM. .Peranan Pemerintah Desa dalam Menggerakkan Partisispasi

Masyarakat (studi di desa Lobu Kota Kecamatan Touluaan Kabupaten Minahasa Tenggara). Skripsi penulis

Muin, Fatkhul. 2014. Otonomi Daerah dalam Perspektif Pembagian Urusan Pemerintah-Pemerintah Daerah dan Keuangan Daerah. Jurnal Ilmu Hukum, Vol 8, No. 1, Januari-Maret, 2014.

Nazir, Muhammad W. 1999. Metode Penelitian, Edisi Ketiga. Jakarta: Ghalia Indonesia

Republik Indonesia. 2014. Undang-undang No 23 Tahun 2014 tentang Pemerintahan daerah. Lembaran Negara RI Tahun 2014. Sekertariatan Negara. Jakarta 
96 Rini Puji Lestari, dkk., Analisis Modal Sosial untuk Kesejahteraan Masyarakat Lokal

Sugiyono. 2012. Memahami Penelitian Kualitatif. Bandung: Alfabeta

Sugiyono. 2012. Metode Penelitian Kombinasi: Mixed Metods. Bandung: Alfabeta

Suryono, Agus. 2012. Peranan dan Pemanfaatan Modal Sosial dalam Pengembangan Klaster Studi Pada Klaster Cor Logam Ceper-Klaten Jawa Tengah. Disertasi Universitas Kristen Satya Wacana

Susetyo, dyke. 2011. Analisis Pengaruh Tingkat Investasi, Aglomerasi, Tenaga Kerja Dan Indeks Pembangunan Manusia Terhadap Pertumbuhan Ekonomi Kabupaten/Kota Di Jawa Tengah. Skripsi. Fakultas Ekonomi. Universitas Diponegoro Semarang.

Syahyuti. 2008. Peran Modal Sosial (Social Capital) dalam Perdagangan Hasil Pertanian. Forum Penelitian Agro Ekonomi, Vol 26, No. 1, Juli 2008, hal 32-43
Thobias, Erwin. 2013. Pengaruh Modal Sosial TerhadaP Perilaku Kewirausahaan . Jurnal Acta Diurna, Vol 2, No. 2. 2013

Todaro, P. Michael, dan Stephen C. Smith. 2009. Economic Development/ Eleventh Edition. Eleventh edition. Pearson Education Limited. United Kingdom. Terjemahan Agus Dharma. 2011. Pembangunan Ekonomi/Edisi Kesebelas/Jilid 1. Edisi kesebelas. Airlangga. Jakarta

Tumbel, Tinneke Meiske. 2014. Analisis Bantuan Desa Terhadap Pelaksanaan Pembangunan Desa (Studi Kasus Pada Kecamatan Tareran Kabupaten Minahasa Selatan). Jurnal LPPM Bidang EkoSosBudKum, Volume 1 Nomor 2 Tahun 2014 